\title{
ANALYSIS OF PROTON CONDUCTING SOFC-MICRO GAS TURBINE HYBRID SYSTEM WITH ANODE AND CATHODE RECYCLING AND FUELED BY ETHANOL
}

\author{
Sasmoko ${ }^{1}$, Chung-Jen Tseng ${ }^{2}$, Widya Wijayanti ${ }^{3}$ \\ 1,2 National Central University, Zhongda Rd, Taoyuan City 32001, Taiwan \\ ${ }^{3}$ Brawijaya University, Veteran Rd, Malang City 65145, Indonesia \\ $+886965245915$ \\ E-mail: sasmoko@ymail.com
}

\begin{abstract}
This paper presents a hybrid system that consists of a pSOFC (proton conducting SOFC) stack, a micro gas turbine (MGT), a combustor, a compressor, a heat exchanger, and an external steam reformer. This simulation is based on thermodynamic analysis and is developed using Matlab/Simulink/Thermolib software and validated using published data from the literature. Furthermore, three cases, cases 1, 2, and 3, are analyzed, and the best case, case 2, is installed with anode and cathode recycling, to increase system performance. According to the results, case 2 exhibits the highest system efficiency (72\%) due to high hydrogen production, and the installation of anode and cathode recycling further increases system efficiency up to $79 \%$.
\end{abstract}

Keywords: pSOFC, micro gas turbine, anode and cathode recycling, and ethanol.

\section{INTRODUCTION}

The solid oxide fuel cell (SOFC) is a type of fuel cell appropriate for the power generating system, with an efficiency of up to 54\% [1]. Currently, two types of SOFCs are available pSOFC and OSOFC (oxygen ion conducting SOFC) which differ in the electrolyte material and operating temperature used. The simulation in this study uses pSOFC because of its advantages such as high Nernst potential at a high operating voltage of $0.8 \mathrm{~V}$, low temperature, high electrolyte conductivity, and high hydrogen partial pressure and low steam partial pressure [2-4]. However, pSOFC has high cathode concentration polarization and low energy destruction $[5,6]$.

Some available designs of SOFC are macro-tubular, micro-tubular, and planar [7]. In the energy management system, some SOFCs are combined with a steam or gas turbine (GT) considering combined heat and power (CHP) for minimizing the energy wasted, which can increase system efficiency up to $90 \%[8,9]$. Moreover, an SOFC-GT system can improve the thermodynamic and economic performance of the power generating system [10]. However, this system produces $\mathrm{CO}_{2}$, and $\mathrm{CO}_{2}$ capturing can decrease the overall efficiency by $4 \%$ [11].

The material selection for SOFC-GT requires consideration of parameters such as the electrolyte material used and major components supported [12-16]. This study uses anode support due to its better performance over electrolyte or cathode support, as well as high voltage and power density $[17,18]$. In the anode support, ohmic polarization is the major loss due to the relatively low proton conduction of the electrolyte [19]. The recycling of SOFC flue gas is currently considered a good solution to increase SOFC performance. Some advantages of recycling installation include an increase in fuel utilization and no steam being supplied to the reforming process [20-28].

Currently, some SOFCs are installed with a reformer to expand the options of fuel used. In the reformer, hydrogen production is affected by the water content and reformer temperature [29]. Furthermore, a minimal amount of steam generation can lead to carbon formation, while excess steam generation can decrease SOFC performance due to decrease in SOFC temperature [30-33]. Thus, in our simulation, the steam to fuel ratio is fixed based on the simulation results.

In the system configuration, recycling installation is divided into three categories: anode recycling, cathode recycling, and a combination of anode and cathode recycling. Anode recycling is installed to recirculate the flue gas to increase SOFC efficiency, while 
cathode recycling is installed to recirculate hot air to the cathode side in order to increase the temperature of pSOFC and decrease air stoichiometry. Moreover, cathode recycling can decrease the amount of water supplied from the pump, or can be stopped because of the generation of water by SOFC $[22,34]$.

\section{METHODOLOGY}

This study models a pSOFC hybrid system based on planar pSOFC technology and integrates it with a micro gas turbine (MGT) and other components. This model is based on thermodynamic analysis and is developed using Matlab version 7.6/Simulink 7.1/Thermolib software.

\section{a. Proton Conducting Solid Oxide Fuel Cell} (P-SOFC)

In pSOFC, hydrogen is first fed to the anode side and then oxidized to form hydrogen protons $\left(\mathrm{H}^{+}\right)$and electrons $\left(\mathrm{e}^{-}\right)$at the anodeelectrolyte interface. The electrons flow through an external load to generate electricity, while hydrogen protons are transported through the proton-conducting electrolyte to the cathode side. Furthermore, $\mathrm{O}_{2}$ flows from the anode side to the cathode-electrolyte interface and reacts with hydrogen protons $\left(\mathrm{H}^{+}\right)$and electrons $\left(\mathrm{e}^{-}\right)$to produce water at the cathode side. Following electrochemical reactions take place in pSOFC:

(1)

Anode: $\mathrm{H}_{2} \rightarrow 2 \mathrm{H}^{+}+2 e^{-}$

$$
\begin{aligned}
& \text { Cathode: } 2 \mathrm{H}^{+}+\frac{1}{2} \mathrm{O}_{2}+2 e^{-} \rightarrow \mathrm{H}_{2} \mathrm{O} \\
& \text { Overall: } \mathrm{H}_{2}+\frac{1}{2} \mathrm{O}_{2} \rightarrow \mathrm{H}_{2} \mathrm{O}
\end{aligned}
$$

The open-circuit voltage ( $\left.E^{\circ c v}\right)$ generated by $p$ SOFC can be described by the Nernst equation as:

$$
E^{o v c}=E^{0}-\frac{R T}{2 F} \ln \left(\frac{P_{H_{2} O_{(c)}}}{P_{H_{2}(a)} P_{2(c)}}\right)
$$

"a" and "b" are anode and cathode, respectively, and $E^{\circ c v}$ is the open-circuit voltage at the standard pressure and is a function of operating temperature [4]:

$$
E^{0}=1.253-2.451 \times 10^{-4} T
$$

Ideally, Eocv is the maximum voltage that can achieve by a fuel cell. However, voltage is always less than Eocv because internal resistance and overpotential losses associated with the electrochemical reactions at the electrolyte interface. There are three major types of fuel cell losses: ohmic polarization, activation polarization, and concentration polarization. The polarizations are based on fixed values as shown in Table 2.1. The operating cell voltage can be given as:

$$
V=E^{o c v}-\left(\eta_{\text {act }}+\eta_{\text {ohm }}+\eta_{\text {conc }}\right)
$$

Ohmic polarization occurs because electrical resistance in the cell, such as resistance to ion flow in the electrolyte, resistance to electron and ion flow through the electrode, and resistance to electron flow through the terminal connection. Ohmic polarization can be written as:

$$
\eta_{\text {ohm }}=i \times R_{e}
$$

Activation polarization occurs when the charge transfer reaction is slow across the electrode-electrolyte interface and a portion of the electrode potential is lost in driving the electron transfer rate up to the rate required by the current demand. Activation polarization can be written as following equations [17]:

$$
\begin{aligned}
& \eta_{a c t, a}=\frac{2 R T}{n_{n_{F}} F} \sinh ^{-1}\left(\frac{i}{2 i_{o a}}\right) \\
& \eta_{a c t, c}=\frac{2 R T}{n_{e} F} \sinh ^{-1}\left(\frac{i}{2 i_{o c}}\right)
\end{aligned}
$$

Concentration polarization is caused by the mass transfer limitation on the availability of the reactants in the vicinity of the electrodeelectrolyte interface. It can be written as [19]:

$$
\begin{aligned}
& \eta_{\text {conc }, a}=\frac{R T}{2 F} \ln \left(\frac{P_{H_{2(a)}}}{P_{H_{2}(a)}^{I}}\right) \\
& \eta_{\text {conc }, c}=\frac{R T}{2 F} \ln \left(\left(\frac{P_{O_{2(c)}}}{P_{O_{2}}^{I}}\right)^{0.5} \frac{P_{H_{2} O}^{I}}{P_{H_{2} O}}\right)
\end{aligned}
$$

\section{b. Splitter of Anode and Cathode}

The splitter divides an incoming flow into two, based on the pressure feedback at the input, and the recycling ratio is defined as: 


$$
\eta_{\text {recycling }}=\frac{m_{\text {recycling }}}{m_{\text {out }}}
$$

\section{c. Micro Gas Turbine (MGT)}

The Turbine (Isentropic) block decreases the pressure of an incoming flow to a given outlet pressure. It determines the thermodynamic state of the outgoing flow along with the produced mechanical power at given isentropic efficiency. The efficiency is retrieved by a lookup table as a function of the molar flow and is defined as ratio of actual enthalpy difference to enthalpy difference for isentropic change of state with the same pressure drop. First law of thermodynamics for turbine:

$$
\begin{aligned}
& \dot{m}\left(h_{\text {in }}-h_{\text {out }}\right)=\dot{W}_{t} \\
& \eta_{t}=\frac{\dot{W}_{t, a c}}{\dot{W}_{t, s}} \\
& \eta_{\text {isentropic }}=\frac{\Delta \dot{h}}{\Delta h_{\text {isentropic }}}
\end{aligned}
$$

Subscripts ' $s$ ' and 'ac' states for isentropic and actual change of state. Turbine is adiabatic and should be used with gaseous flows.

Table 1. Assumed values

\begin{tabular}{ll}
\hline Parameter & Value \\
\hline p-SOFC & 3 \\
Operating pressure, P (atm) & 85 \\
Fuel Utilization (\%) & 3.5 \\
Steam to fuel & 50 \\
Amount of stack & 0.04 \\
Cell length, $L(\mathrm{~m})$ & 0.01 \\
Cell width, $\mathrm{W}(\mathrm{m})$ & 0.4 \\
Electrode porosity, $\varepsilon$ & 0.5 \\
Electrode pore radius, $\mathrm{r}(\mu \mathrm{m})$ & 5.0 \\
Electrode tortuosity, $\xi$ & 225 exp \\
Electrode conductivity, $\vartheta_{\text {electrolyte }}\left(\Omega^{-}\right.$ & $\left(-6 \times 10^{3} / \mathrm{T}\right)$ \\
$\left.{ }^{1} \mathrm{~m}^{-1}\right)$ [12] & $8.98 \times 10^{-5}$ \\
Effective diffusion coefficient at the & \\
anode side, $\mathrm{D}_{\mathrm{a}, \text { eff }}\left(\mathrm{m}^{2} / \mathrm{s}\right)$ & $6.31 \times 10^{-6}$ \\
Effective diffusion coefficient at the & \\
cathode side, $\mathrm{D}_{\mathrm{c}, \mathrm{eff}}\left(\mathrm{m}^{2} / \mathrm{s}\right)$ & 500 \\
Anode thickness $(\mu \mathrm{m})$ & 50 \\
Cathode thickness $(\mu \mathrm{m})$ & 50 \\
Electrolyte thickness $(\mu \mathrm{m})$ & 83 \\
Turbine efficiency $(\%)$ & 78 \\
Compressor efficiency $(\%)$ & \\
\hline
\end{tabular}

\section{d. System Design}

This study analyzes three cases. Case 1 (Fig. 1), where air is initially compressed by a compressor and then heated up in a heat exchanger before flowing to the cathode side, and ethanol and water are mixed and flow into the reformer. Furthermore, the hydrogen produced by the reformer reacts with air in the fuel cell. Subsequently, the unreacted air and hydrogen are burnt in the combustor and flow into the MGT. The gas output from the GT flows directly into the reformer. The gas output from the reformer is used for pSOFC cooling because the gas temperature is only $89{ }^{\circ} \mathrm{C}$. After cooling, the gas temperature is increased to $446{ }^{\circ} \mathrm{C}$ and used to heat up the air heat exchanger. In case 2 (Fig. 2), the gas output from the gas turbine flows into the fuel heat exchanger to increase hydrogen production. Furthermore, the gas flows into the reformer and pSOFC cools. In case 3 (Fig. 3), the gas output from the reformer (red line) flows into the air heat exchanger.

In the presenting the data, the simulation in our study applies the following equation to calculate efficiency. The electrical efficiency from $\mathrm{pSOFC}$ is defined as the ratio of electrical power produced by pSOFC to the chemical energy in fuel represented by the lower heating value of fuel multiplied by mass flow rate of fuel as shown in the following equation:

$$
\eta_{S O F C}=\frac{P_{S O F C}}{\dot{m}_{f} \times L H V}
$$

Besides SOFC stack, compressor and GT of hybrid system also play important roles in determining the overall performance of the system. The power system and combine power and heat (CHP) efficiency is determined as follows:

$$
\begin{aligned}
& \eta_{\text {Power System }}=\frac{P_{\text {SOFC }}+P_{M G T}-P_{\text {Comp }}}{\dot{m}_{f} \times L H V} \\
& \eta_{C H P}=\frac{P_{S O F C}+P_{M G T}+Q_{U s e f u l}+P_{\text {Comp }}}{\dot{m}_{f} \times L H F}
\end{aligned}
$$

where $\mathrm{P}_{\text {MGT }}$ and $\mathrm{P}_{\text {Comp }}$ are net power produced by MGT and power consumed by compressor during process, respectively. Quseful is net heat energy can be utilized for heating water from exhaust gas. 


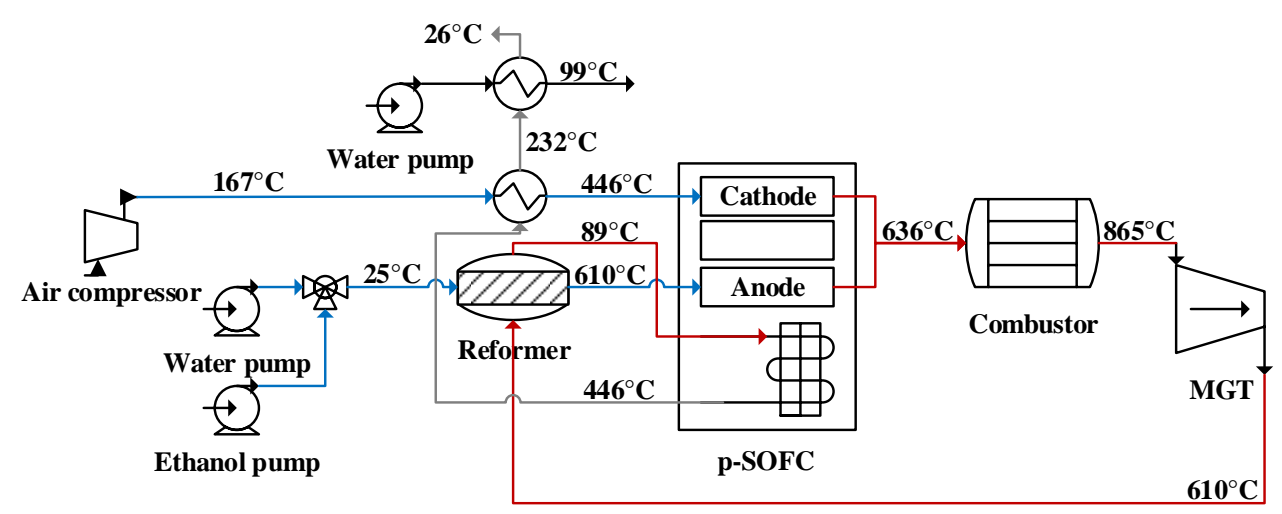

Figure 1. Case 1 without fuel heater before reformer.

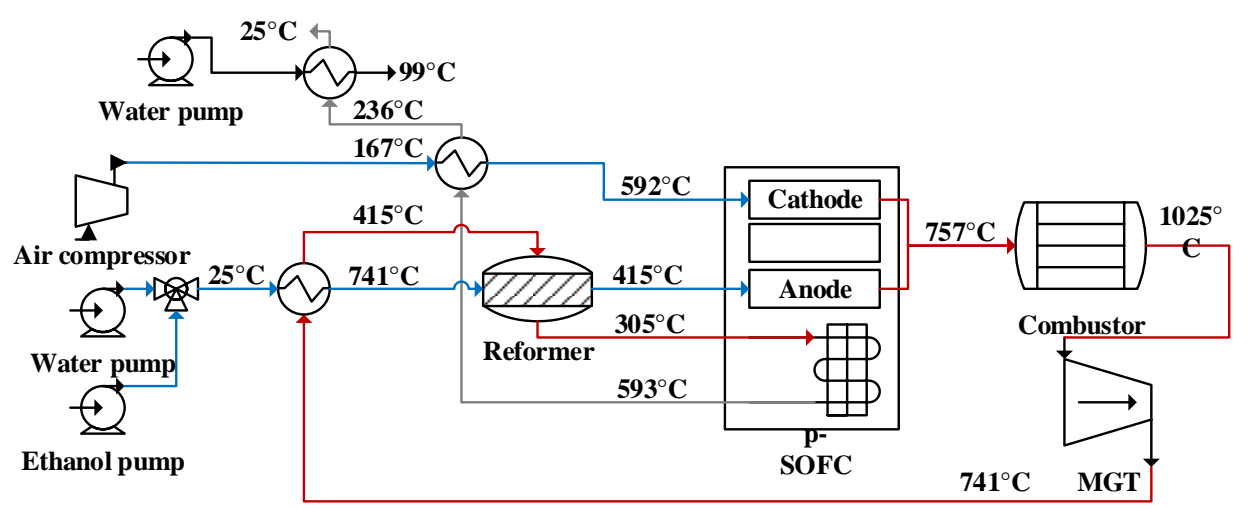

Figure 2. Case 2 with fuel heater before reformer.

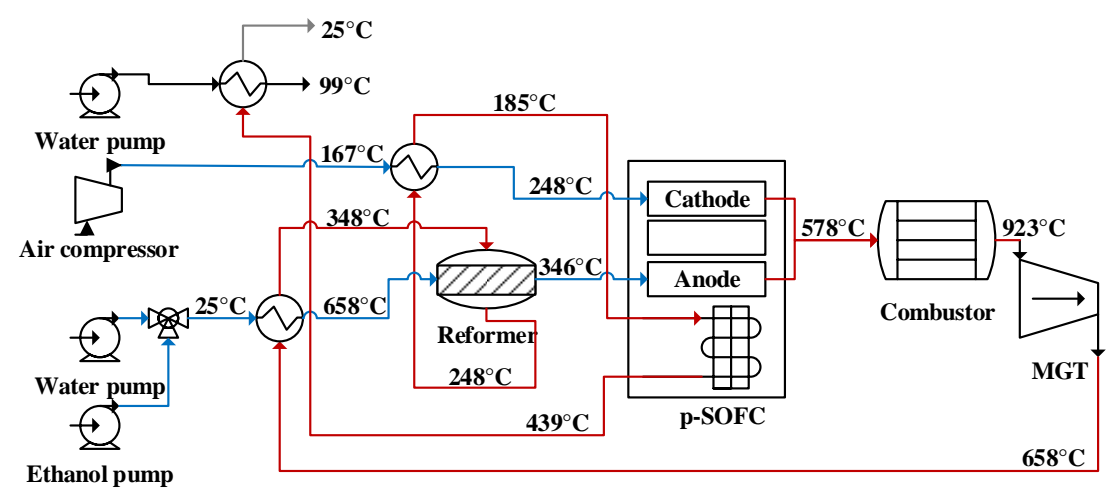

Figure 3. Case 3 with fuel heater before reformer but different line.

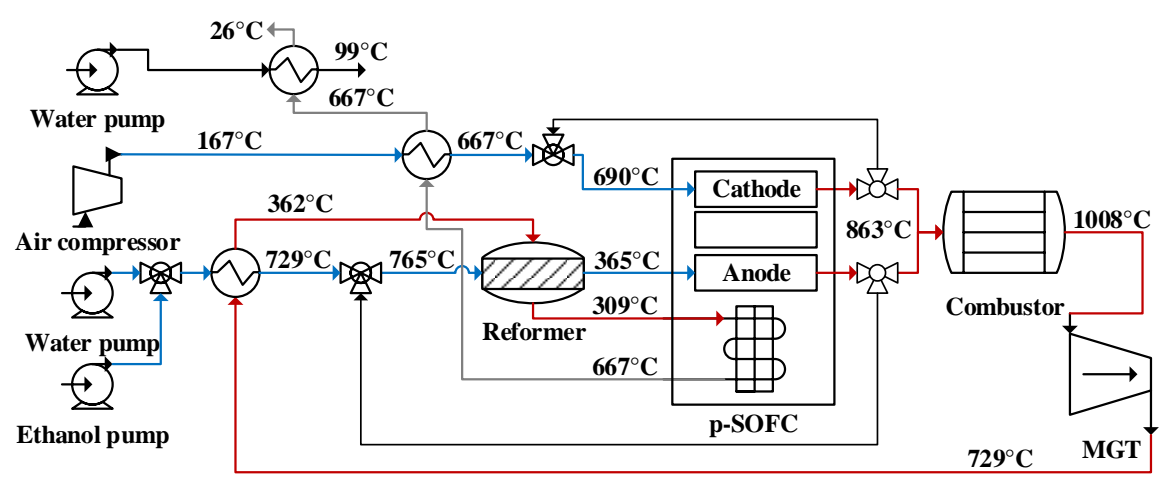

Figure 4. Case 2 with anode recycling of $40 \%$ and cathode recycling of $10 \%$. 
The models are typical lumpedparameter model based on following assumptions:

1. A mixture of the species is assumed to be ideal.

2. The flow is assumed to be steady state.

3. All flows are one dimensional.

4. Components do not leak any fluid to the surrounding.

5. Potential and kinetic energy are neglected for all components.

6. The heat loss from the components to the surrounding is 5 percent for combustor chamber.

Nomenclature

\begin{tabular}{|c|c|}
\hline$F$ & Faraday's constant, $\mathrm{C} / \mathrm{mol}$ \\
\hline$h_{\text {in }}$ & Enthalpy input, $\mathrm{J} / \mathrm{g}$ \\
\hline hout & Enthalpy output, J/g \\
\hline i & Current density, $\mathrm{A} / \mathrm{m}^{2}$ \\
\hline ioa & $\begin{array}{l}\text { Anode exchange current } \\
\text { density, } A / \mathrm{m}^{2}\end{array}$ \\
\hline ioc & $\begin{array}{l}\text { Cathode exchange current } \\
\text { density, } A / \mathrm{m}^{2}\end{array}$ \\
\hline $\begin{array}{l}\mathrm{mout} \\
\mathrm{mol} / \mathrm{s}\end{array}$ & The amount of exit gas, \\
\hline mrecycling & $\begin{array}{l}\text { The amount of recycled gas, } \\
\mathrm{mol} / \mathrm{s}\end{array}$ \\
\hline$n_{e}$ & $\begin{array}{l}\text { Electrons transferred per } \\
\text { reaction }\end{array}$ \\
\hline$P_{(a)}$ & $\begin{array}{l}\text { Absolute pressure at the } \\
\text { anode side, } \mathrm{kPa}\end{array}$ \\
\hline$P_{(c)}$ & $\begin{array}{l}\text { Absolute pressure at } \\
\text { cathode side, } \mathrm{kPa}\end{array}$ \\
\hline $\mathrm{R}$ & Gas constant, $\mathrm{kJ} /(\mathrm{mol} \mathrm{K})$ \\
\hline $\mathrm{R}_{\mathrm{e}}$ & $\begin{array}{l}\text { Electrolyte area-specific } \\
\text { ohmic resistance, } \Omega / \mathrm{m}^{2}\end{array}$ \\
\hline TIT & Turbine inlet temperature, ${ }^{\circ} \mathrm{C}$ \\
\hline V & Operating cell voltage, $\mathrm{V}$ \\
\hline
\end{tabular}

\section{e. Validation}

The electrochemical model was numerically solved in Matlab to predict the caracteristic performance of pSOFC. Fig. 5 shows that a model prediction of the I-V curve characteristics of pSOFC operating at 800 , 900 , and $1000{ }^{\circ} \mathrm{C}$ and a pressure of $1 \mathrm{~atm}$ gives an accurate prediction of experimental data.

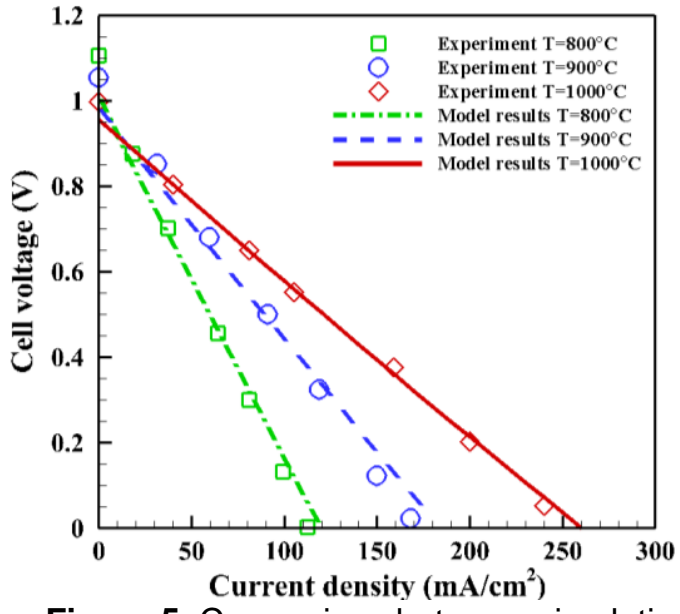

Figure 5. Comparison between simulation results and experiment data by Iwahara [35].

\section{RESULTS AND DISCUSSION}

\section{a. Case Comparisons}

The case comparison presented in Table 2 shows that case 2 has the highest efficiency because the temperature input of the reformer is as high as $741^{\circ} \mathrm{C}$. Consequently, the reaction rate between the steam and ethanol gas increases, thus increasing hydrogen production and the produced current. Furthermore, voltage in case 2 is the highest because it has the highest pSOFC temperature (Fig. 2). An increase in pSOFC temperature indicates an increase in gas enthalpy, which increases the turbine inlet temperature (TIT), and subsequently, the MGT power $[36,37]$. Case 3 has the lowest efficiency and power due to low temperature inlet at the anode and cathode sides (Fig. 3) [38-41].

\section{b. Anode Recycling}

Anode recycling refers to the recirculation of output gas from the anode side to the reformer (as shown in Fig. 4). Increasing the anode recycling from $0 \%$ to $40 \%$ can increase the current produced due to an increase in the hydrogen mass flow rate (Fig. 6). Furthermore, the pSOFC temperature increases from $727^{\circ} \mathrm{C}$ to $863^{\circ} \mathrm{C}$, which causes an increase in voltage. Consequently, pSOFC power increases from $3818 \mathrm{~W}$ to $4170 \mathrm{~W}$ (Fig. 7).

The effect of anode recycling on MGT is shown in Fig. 8, wherein the MGT power decreases at anode recycling from $0 \%$ to $20 \%$ due to a decrease in TIT. Furthermore, the MGT power increases from $20 \%$ to $40 \%$. The 
phenomenon of anode recycling shows that increasing the pSOFC temperature has a good effect on the combustor, even though the fuel supplied to the combustor is decreasing.

Table 2. The results of pSOFC-MGT system.

\begin{tabular}{llll}
\hline \multicolumn{1}{c}{ Parameter } & Case 1 & Case 2 & Case 3 \\
\hline pSOFC eff (\%) & 56.1 & 57.0 & 43.9 \\
System eff (\%) & 69.0 & 72.9 & 57.9 \\
CHP eff (\%) & 75.8 & 79.5 & 63.5 \\
SOFC power (W) & 3735 & 3796 & 2924 \\
MGT power (W) & 1368 & 1565 & 1440 \\
Current (A) & 96.7 & 91.9 & 84.8 \\
Voltage (V) & 38.6 & 41.2 & 34.4 \\
TIT (으) & 865 & 1025 & 923 \\
\hline
\end{tabular}

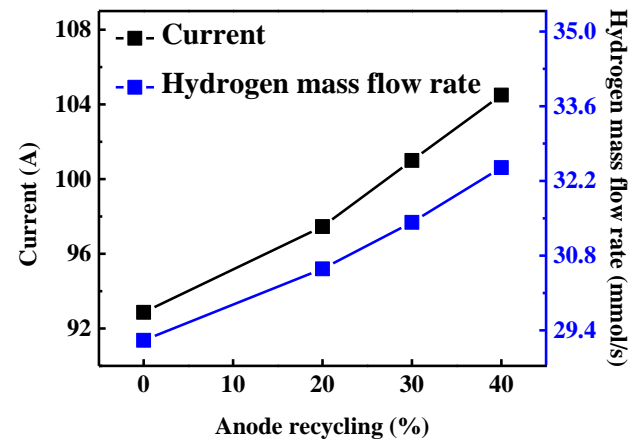

Figure 6. Anode recycling effect on current and hydrogen mass flow rate.

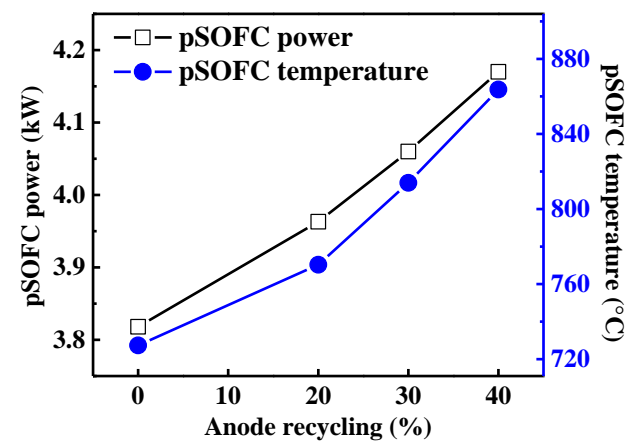

Figure 7. Anode recycling effect on pSOFC power and temperature.

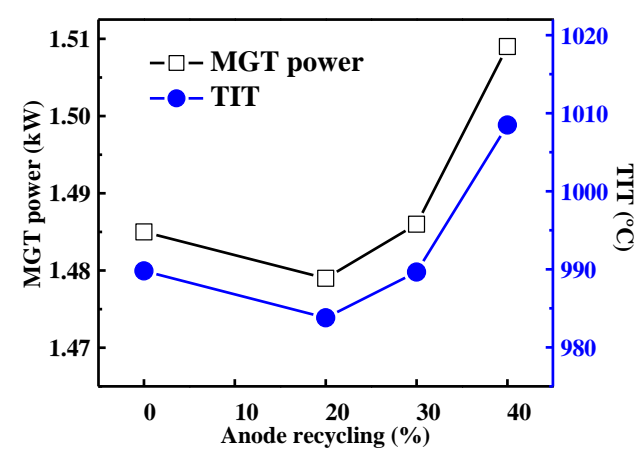

Figure 8. Anode recycling effect on MGT power and TIT.

\section{c. Cathode Recycling}

Cathode recycling refers to gas recirculation from the cathode output to the cathode input (Fig. 4). Fig. 9 shows that using cathode recycling from $0 \%$ to $40 \%$ can increase the pSOFC power from $3818 \mathrm{~W}$ to $3887 \mathrm{~W}$, which is due to an increase in the air inlet temperature of pSOFC from $578{ }^{\circ} \mathrm{C}$ to 743 ${ }^{\circ} \mathrm{C}$. As we know that increasing the temperature increases the chaos level of the molecule, air will react more easily with hydrogen. Furthermore, air stoichiometry affects the pSOFC temperature because the excess air supplied can decrease the pSOFC temperature. Consequently, an increase in cathode recycling must be accompanied by a decrease in air stoichiometry to maintain the air flow rate and temperature on the cathode side, as shown in Fig. 10. The results show that the compressor power decreases from $483 \mathrm{~W}$ to $407 \mathrm{~W}$.

Nevertheless, cathode recycling decreases the MGT power due to a decrease in the mass flow rate, as shown in Fig. 11. The phenomenon shows that cathode recycling not only increases pSOFC power but also decreases MGT power, even with increasing TIT.

\section{d. Combination Of Anode And Cathode Recycling}

This section presents an analysis of a combination of cathode and anode recycling to improve system performance. Fig. 12 shows that a combination of $40 \%$ cathode recycling and $40 \%$ anode recycling produces the highest pSOFC power. Moreover, all cathode recycling systems from $10 \%$ to $40 \%$ have the same pSOFC power at $40 \%$ anode recycling. Thus, 
an increase in pSOFC power due to an increase in the hydrogen and air mass flow rate can produce more current. Fig. 13 shows that the recycling combination has a strong effect when the anode recycling is set at more than $20 \%$ due to the significant temperature increase. Moreover, the MGT power decreases under the same condition of anode recycling due to the decrease in the mass flow rate.

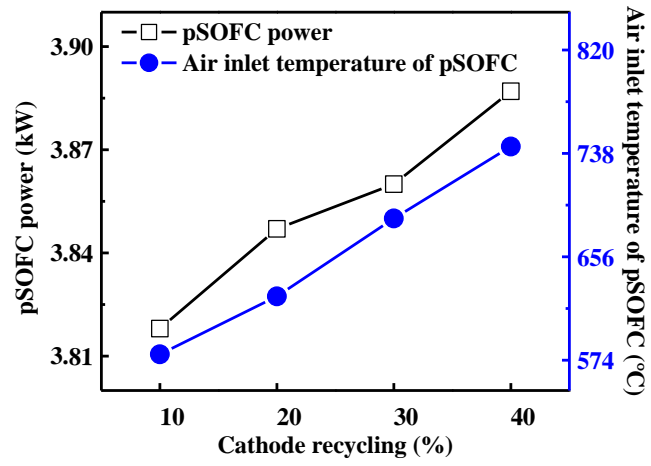

Figure 9. Cathode recycling effect on pSOFC power and air inlet temperature.

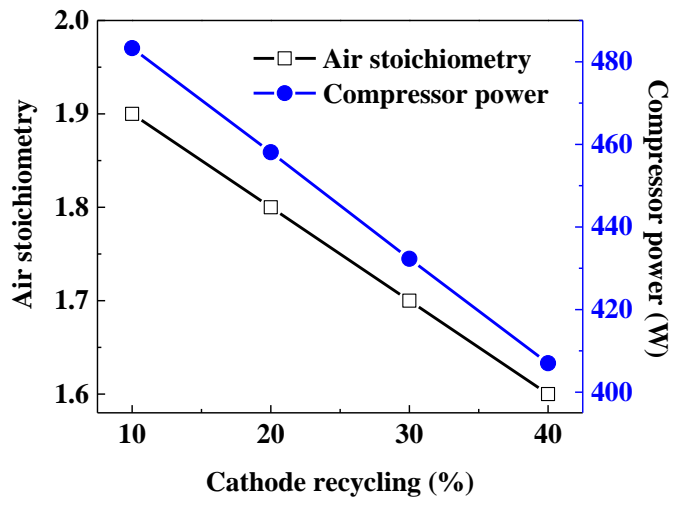

Figure 10. Cathode recycling effect on air stoichiometry and compressor power.

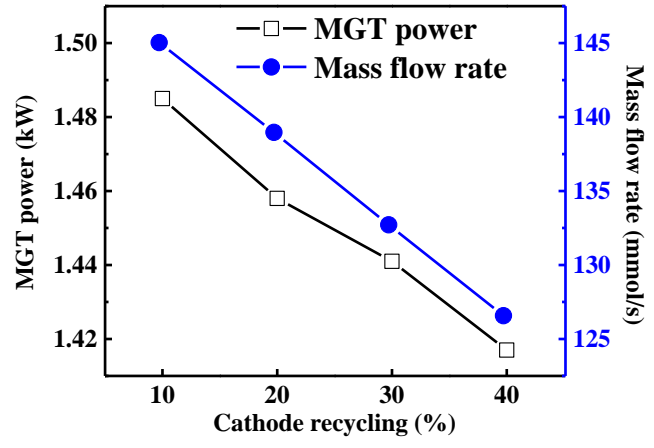

Figure 11. Cathode recycling effect on MGT power and mass flow rate.

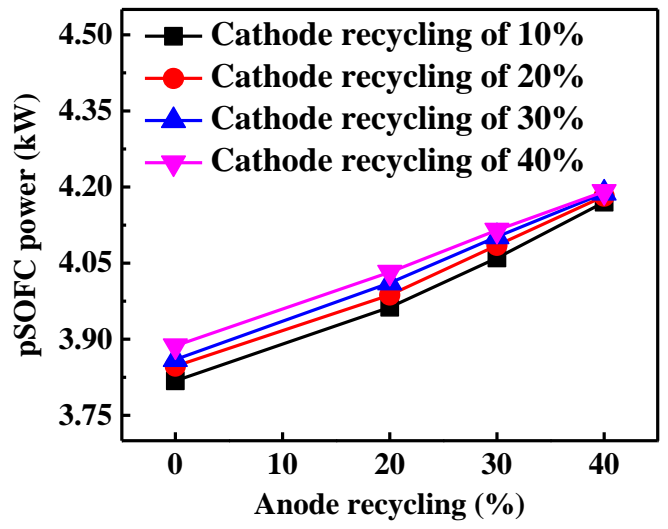

Figure 12. Anode and cathode recycling effect on pSOFC power.

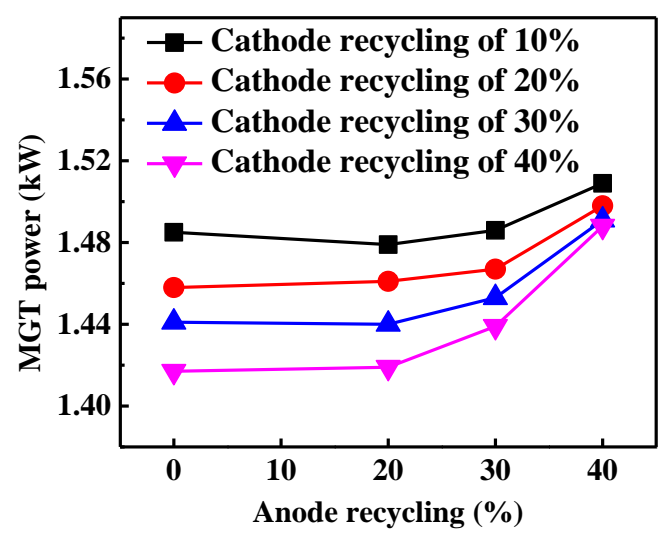

Figure 13. Anode and cathode recycling effect on MGT power. 


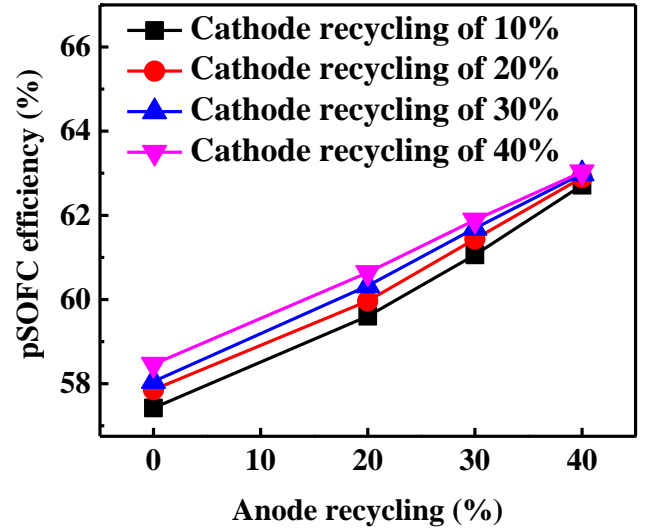

Figure 14. Anode and cathode recycling effect on pSOFC efficiency.

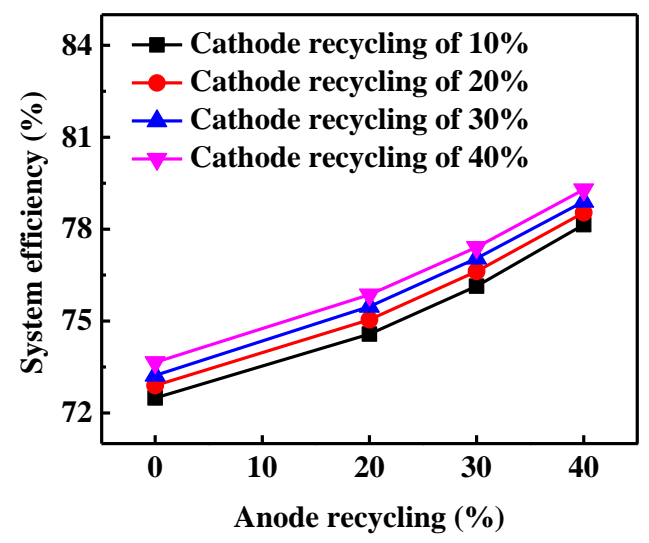

Figure 15. Anode and cathode recycling effect on system efficiency.

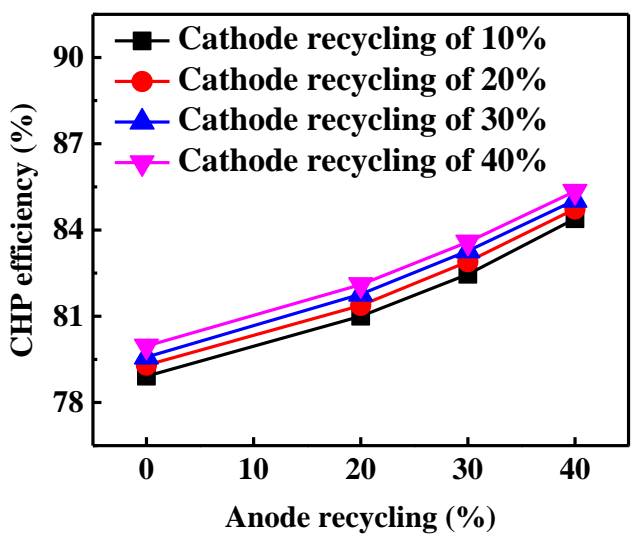

Figure 16. Anode and cathode recycling effect on CHP efficiency.
Fig. 14 shows that the combination of cathode and anode recycling can increase pSOFC efficiency from $57 \%$ to $63 \%$. This increase shows that the recirculation of pSOFC flue gas can produce more power than that burnt into combustion for driving an MGT. Moreover, a decrease in MGT power, as shown in Fig. 11, can be prevented by combination with anode recycling. This decrease has no effect on system efficiency (Fig. 15) because of a significant increase in pSOFC power and a decrease in compressor power. Furthermore, CHP efficiency increases from $78 \%$ to $85 \%$ where the exhaust gas is kept constant at $25^{\circ} \mathrm{C}$ (Fig. 16).

\section{CONCLUSIONS}

From the viewpoint of parameters such as pSOFC and MGT performance, Case 2 presented the best system configuration. It was combined with anode and cathode recycling to further improve the performance. System efficiency of case 2 was only $72 \%$ in the beginning, but increased up to $79 \%$ by using cathode and anode recycling.

The phenomenon of anode recycling shows that increasing the pSOFC temperature has a good effect on the combustor even though the fuel supplied to the combustor is decreasing. However, cathode recycling decreases the MGT power due to a decrease in the mass flow rate. Therefore, cathode recycling not only increases pSOFC power but also decreases MGT power, even with increasing TIT. The decrease in MGT power can be prevented by using a combination of cathode and anode recycling.

\section{ACKNOWLEDGEMENTS}

The research is supported by Ministry of Science and Technology (MOST NO. 1053113-E-008-003). 


\section{REFERENCES}

[1] P. Yaneeporn, P. Woranee, A. Suttichai, A. Amornchai, International Journal of Hydrogen Energy, 35 4301-4310 (2010).

[2] N. Meng, International Journal of Hydrogen Energy, 38 2846-2858 (2013).

[3] N. Meng, K. H. L. Michael, Y. C. L. Dennis, Journal of Power Sources, 177 369-379 (2008).

[4] F. Ishak, I. Dincer, C. Zamfirescu, Journal of Power Sources, 202 157-165 (2012).

[5] N. Meng, Y. C. L. Dennis, K. H. L. Michael, Journal of Power Sources, 183133-142 (2008).

[6] F. Abraham, I. Dincer, Journal of Power Sources, 299 544-556 (2015).

[7] A. Buonomano, F. Calise, M. D. d'Accadia, A. Palombo, M. Vicidomini, Applied Energy, 156 32-85 (2015).

[8] J. Pirkandi, M. Ghassemi, M. H. Hamedi, R. Mohammadi, Jounal of cleaner production, 29-30 151-162 (2012).

[9] C. Arnab, H. Chandra, A. Arora, Renewable and Sustainable Energy Reviews, 20 430-442 (2013).

[10] F. Denver, Cheddie, M. Renique, International Journal of Hydrogen Energy, 35 11208-11215 (2010).

[11] L. Q. Duan, K. X. Huang, X. Y. Zhang, Y. P. Yang, Energy, 58 66-77 (2013).

[12] A. R. Potter, R. T. Baker, Solid State Ionic, 177 1917-1924 (2006).

[13] H. Weidong, J. Y. Kyung, S. E. Ryan, G. Srikanth, N. B. Soumendra, B. P. Uday, Journal of Power Sources, 195 532-535 (2010).

[14] C. Zhang, C. J. Li, G. Zhang, X. J. Ning, C. X. Li, H. L. Liao, C. Coddet, Materials Science and Engineering: B, 137 24-30 (2007)

[15] N. Meng, Y. C. L. Dennis, K. H. L. Michael, International Journal of Hydrogen Energy, 33 5765-5772 (2008).

[16] L. Z. Zhu, L. Zhang, A. V. Virkar, Journal of Power Sources, 291 138-155 (2015).

[17] S. H. Chan, K. A. Khor, Z. T. Xia, Jounal of Power Sources, 93 130-140 (2001).

[18] N. Meng, Y. C. L. Dennis, K. H. L. Michael, Journal of Power Sources, 183 687-692 (2008).

[19] P. Yaneeporn, N. P. Brando, P. Woranee, A. Suttichai, A. Amornchai,
Solid State lonics, 181 1568-1576 (2010).

[20] P. Roland, D. Robert, B. Ludger, P. Jari, K. Jari, $\mathrm{H}$. Toumas, International Journal of Hydrogen Energy, 38 6809-6820 (2013).

[21] B. Annamaria, C. Francesco, D. Massimo, P. Adolfo, V. Maria, Applied Energy, 156 32-85 (2015).

[22] J. X. Jia, Q. Li, M. Luo, L.M. Wei, Abuliti Abudula, Energy, 36 1068-1075 (2011).

[23] E. Valerie, Applied Energy, 93 107-115 (2012).

[24] R. W. Mark, L. Jiefeng, G. W. Michael, F. S. Daniel, A. Thomas, Trabold, Applied Energy, 130 94-102 (2014).

[25] U. D. Ralph, O. Jana, L. Andreas, S. Christian. S, Michael. S, Torben. K, Shaofei. C, Christian, L. Reinhard, Journal of Power Sources, 196 7152-7160 (2011).

[26] R. J. Braun, S. A. Klein, D. T. Reindl, Journal of Power Sources, 158 1290-1305 (2005).

[27] W. Stefanie, G. S. Ana, H. Peter, C. Maxime, G. B. Wolfgang, L. François, F. Andreas, Journal of Power Sources, 279 656-666 (2015).

[28] W. Stefanie, G. S. Ana, H. Peter, C. Maxime, G. B. Wolfgang, L. François, F. Andreas, Journal of Power Sources, 282 498-510 (2015).

[29] T. Chollaphan, P. Yaneeporn, P. Pimporn, A. Amornchai, International Journal of Hydrogen Energy, 40 6950-6958 (2015).

[30] D. Cocco, V. Tola, Energy, 34 2124-2130 (2009).

[31] S. Assabumrungrat, N. Laosiripojanab, V. Pavarajarna, W. Sangtongkitcharoena, A. Tangjitmateea, P. Praserthdama, Journal of Power Sources, 139 55-60 (2005).

[32] D. Wayne, R. Anthony, K. David, Journal of Power Sources, 277 292-303 (2015).

[33] P. Jamasb, G. Majid, H. H. Mohammad, M. Rafat, Journal of Cleaner Production, 2930 151-162 (2012).

[34] Z. Farshid, S. F. Alan, Energy Conversion and Management, 76 571-580 (2013).

[35] H. Iwahara, Solid State Ionics, 1 573-578 (1987).

[36] Y. Haseli, I. Dincer, G. F. Naterer, International Journal of Hydrogen Energy, 33 5811-5822 (2008).

[37] Y. Haseli, I. Dincer, G. F. Natere, Thermochimica Arta, 480 1-9 (2008). 
[38] Y. Jie, L. Xi, H. J. Jian, J. Li, Z. Lei, G. J. Jin, G. W. Xiao, H. X. Lin, International Journal of Hydrogen Energy, 36 61606174 (2011).
[40] M. Mehdi, A. Sepide, V. Ali, A. R. Marc, International Journal of Hydrogen Energy, 39 21196-21214 (2014).

[41] A. Arpornwichanop, Y. Patcharavorachot, S. Assabumrungrat, Chemical Engineering Science, 65 581-589 (2010).

[39] V. Yurkiv, Electrochimica Acta, 143 114128 (2014), 